\title{
PENGARUH PROMOSI DAN KUALITAS PELAYANAN TERHADAP PENINGKATAN JUMLAH PENERIMAAN TARUNA DI POLITEKNIK BUMI AKPELNI
}

\author{
Aan Rubiyanto ${ }^{1 *}$ \\ ${ }^{1}$ Program Studi Nautika, Politeknik Bumi Akpelni \\ Jln. Pawiyatan Luhur II/17 Bendan Dhuwur Semarang \\ "email : aan@akpelni.ac.id
}

\begin{abstract}
Abstrak
Penelitian ini bertujuan untuk mengkaji dan menganalisa tentang pengaruh promosi, kualitas pelayanan terhadap peningkatan jumlah Taruna dengan menggunakan metode campuran (mix method). Subjek dalam penelitian ini adalah calon Taruna baru Politeknik Bumi Akpelni (PBA) program studi Nautika angkatan 55 sebanyak 163 orang. Data dikumpulkan melalui wawancara dan kuisioner, selanjutnya dianalisis dengan menggunakan tehnik triangulasi data dan tehnik uji regresi. Hasil penelitian menunjukkan bahwa pengaruh promosi yang dilakukan oleh Politeknik Bumi Akpelni adalah melalui alumni, Taruna aktif, penyebaran brosur, saudara, internet dan PBA expo. Dari pembahasan diperoleh bahwa secara parsial "saudara" memiliki pengaruh yang besar, yaitu sebesar 32,02\%, sedangkan variabel yang paling sedikit pengaruhnya adalah PBA expo yaitu 7,18\%. Variabel alumni, saudara, Taruna aktif, brosur, internet dan PBA expo secara serentak berpengaruh signifikan terhadap peningkatan jumlah Taruna yaitu sebesar 97,35\%, sedangkan sisanya 2,65\% dipengaruhi oleh variabel lain. Dalam kajian ini, dapat disimpulkan bahwa kualitas pelayanan yang baik menjadi penting karena akan berdampak langsung pada citra dan keuntungan lembaga. Oleh sebab itu, sangat penting untuk mempertimbangkan aspek kepuasan pelanggan terkait dengan kualitas pelayanan yang diberikan. Disisi lain, adanya faktor penghambat seperti biaya promosi yang kurang cukup, dan tidak dimilikinya Sumber Daya Manusia dalam bidang ilmu komunikasi perlu menjadi hal penting yang harus diperhatikan.
\end{abstract}

Kata kunci: Promosi, Kualitas Pelayanan, Peningkatan Jumlah Taruna

\section{PENDAHULUAN}

Perguruan tinggi merupakan suatu wadah yang digunakan sebagai lembaga Research and Development serta arena pembentukan karakter manusia untuk menghasilkan generasi yang memiliki kepribadian serta kompetensi.

Saat ini, apabila seseorang memilih memasuki suatu Perguruan Tinggi, maka orang tersebut membeli jasa Pendidikan Tinggi. Keputusan untuk masuk dalam suatu Perguruan Tinggi merupakan suatu keputusan investasi. Investasi tersebut harus menguntungkan konsumen setelah dinyatakan lulus dari sekolah asalnya. Hal tersebut dikarenakan selain membutuhkan biaya yang besar, kuliah di Perguruan Tinggi juga menghabiskan waktu yang cukup lama. Apalagi Perguruan tingi seperti Politeknik Bumi Akpelni, dilihat dari segi waktu dan biaya yang membutuhkan waktu lama dan membutuhkan biaya besar. Oleh karena itu, konsumen Perguruan Tinggi harus memiliki strategi dalam memilih suatu perguruan tinggi yang baik dan berkualitas. Persaingan pada industri pendidikan tinggi dalam memperebutkan Calon Taruna sudah mulai semakin ketat. Hal ini ditambah lagi dengan perguruan tinggi swasta di Indonesia yang saat ini sudah tumbuh subur dan pesat. Dengan kondisi tersebut, bagi Perguruan Tinggi yang sudah lama berdiri tetap akan meningkatkan promosi untuk mendapatkan Calon Taruna.

Menurut Lupiyoadi (2001), alasan lain yang menyebabkan persaingan lembaga pendidikan tinggi semakin ketat adalah adanya Peraturan Pemerintah Nomor 61 Tahun 1999 tentang Otonomi Perguruan inggi. Melalui PP tersebut, pemerintah memberikan kesempatan kepada setiap 
Perguruan Tinggi (PT) untuk melahirkan manajemen yang lebih efisien dan berdampak pada pengembangan keilmuan lewat otonomi Perguruan Tinggi. Selain itu, Perguruan Tinggi Swasta juga diberi kesempatan untuk tumbuh dan berkembang sejajar dengan Perguruan Tinggi Negeri.

Untuk mengatasi hal tersebut, penyelenggara pendidikan tinggi perlu mengelola organisasinya seperti layaknya suatu bisnis dengan tidak meninggalkan aspek idealnya. Konsep pemasaran harus diterapkan dalam mengelola organisasi. Pemasaran bukan lagi merupakan aktivitas fungsional bagian pemasaran saja melainkan merupakan bagian yang utuh dari suatu organisasi. Perusahaan harus mampu untuk mentransformasi dirinya menjadi the marketing company untuk bersaing secara global. Kunci penting dalam pemasaran adalah komunikasi yang efektif, dimana pesan-pesan dikonstruksi berdasarkan tujuan yang diharapkan. Penyusunan (konstruksi) pesan ini tidak bisa melupakan segmentasi pasar yang ingin diraih. Instrumen dasar yang digunakan untuk mencapai tujuan komunikasi suatu perusahaan atau organisasi adalah bagaimana promosi yang efektif dengan kualitas pelayanan mengacu kepada bauran promosi (promotion mix.)

Politeknik Bumi Akpelni Semarang adalah kampus yang membentuk karakter pada anak didiknya. Berdiri sejak tahun 1964 dengan program pendidikan vokasi jenjang Program Diploma III (D3) yang terdiri dari tiga (3) Program Studi yaitu Program Studi Nautika, Program Studi Teknika, Program Studi Ketatalaksanaan Pelayaran Niaga, dan pada tahun 2019 telah dibuka Program Studi baru yaitu Program Studi Transportasi Laut jenjang program Diploma IV (D.4)

Selain itu, dari hasil wawancara awal dengan para Calon Taruna Politeknik Bumi Akpelni belum menjadi pilihan utama apabila dibandingkan dengan Perguruan Tinggi Negeri. Untuk mengatasi persaingan ketat tersebut, menuntut tim promosi Politeknik Bumi Akpelni harus bekerja keras untuk meningkatkan jumlah penerimaan calon Taruna baru dengan berbagai strategi. Penelitian ini dilakukan kepada calon Taruna TA. 2019-2020, tahun akademik ini dipilih karena dari hasil data awal yang didapatkan menunjukkan bauran promosi yang digunakan lebih baru dan beragam.

Tujuan umum penelitian ini adalah untuk menganalisis pengaruh promosi, kualitas pelayanan, terhadap peningkatan penerimaan Taruna Baru dengan menggunakan metode campuran (mix method).

\section{TINJAUAN PUSTAKA}

\section{Promosi}

Promosi menurut Susatyo Herlambang, (2014) berpendapat bahwa kegiatan yang dilakukan oleh perusahaan atau lembaga untuk mengkomunikasikan manfaat dari produknya dan untuk meyakinkan konsumen sasaran untuk membeli produknya

Menurut Hamdani dalam Sunyoto, (2013) promosi merupakan salah satu variabel dalam bauran pemasaran yang sangat penting dilaksanakan oleh perusahaan dalam memasarkan produk. Sedangkan menurut Alma (2005) mengatakan bahwa promosi adalah jenis komunikasi yang memberi penjelasan yang meyakinkan calon konsumen tentang barang dan jasa. Hal ini bertujuan untuk perhatian, mendidik, mengingatkan, dan meyakinkan calon konsumen.

\section{Kualitas Layanan}

Supranto (2006) menyatakan bahwa Kualitas Layanan adalah sebuah kata yang dibagi penyedia jasa merupakan sesuatu yang harus dikerjakan dengan baik. Sedangkan menurut Tjiptono dan Chandra (2012) dalam rangka menciptakan kepuasan pelanggan, produk yang ditawarkan organisasi harus berkualitas. Istilah kualitas sendiri mengandung bebagai macam penafsiran, karena kualitas memiliki sejumlah level universal (sama di 
manapun), kultural (tergantung sistem nilai budaya), sosial (dibentuk oleh kelas sosial ekonomi, kelompok etnis, keluarga, teman sepergaulan), dan personal tergantung preferensi atau selera setiap individu. Secara sederhana kualitas bisa diartikan sebagai produk yang bebas cacat. Dengan kata lain, produk sesuai dengan standar (target, sasaran atau persyaratan yang bisa didefinisikan, diobservasi dan diukur).

\section{METODE PENELITIAN}

\section{Lokasi dan Waktu Penelitian}

Penelitian ini dilaksanakan di Politeknik Bumi Akpelni pada Bulan Agustus - Desember 2019.

\section{Informan Penelitian}

Dalam hal mendapatkan informasi menyeluruh tentang pengaruh promosi yang dilakukan Politeknik Bumi Akpelni Semarang, pemilihan informan penelitian dilakukan berdasarkan tujuan penelitian yaitu dengan menggunakan purposive sample (sampel bertujuan). Oleh karena itu, informan yang peneliti anggap relevan dan sesuai dengan tujuan penelitian ini, yaitu Tim Promosi (tenaga struktural dan fungsional yang terlibat) Politeknik Bumi Akpleni Semarang, dan Calon Taruna (Catar) baru tahun 2019 yang telah melakukan registrasi ulang pada Politeknik Bumi Akpleni. Metode sampling untuk Taruna adalah rancangan sampel probalitas (probality sampling design) dengan teknik sampel acak sederhana (simple random sampling).

Tahap berikutnya adalah penentuan besaran jumlah sampel responden yang tersedia dipilih dengan menggunakan menggunakan rumus Slovin (dalam Augusty Ferdinand, 2007), rumusnya adalah :

dimana

$$
n=\frac{N}{1+N d^{2}}
$$

$$
\begin{aligned}
\mathrm{n} & =\text { Jumlah sampel } \\
\mathrm{N} & =\text { ukuran populasi } \\
\mathrm{D} & =\text { persentase kelonggaran ketidak }
\end{aligned}
$$

telitian karena kesalahan pengambilan sampel yang ditolerir dimana ditetapkan 5\%.

Berdasarkan jumlah populasi calon Taruna tahun akademik 2019-2020 sebanyak 153 orang dengan menggunakan rumus Slovin dan tingkat kesalahan pengambilan sampel yang ditolerir ditetapkan 5\% maka jumlah sampel dalam penelitian diperoleh 110 orang Calon Taruna.

\section{Metode Pengumpulan Data}

Teknik pengumpulan data dilakukan dengan menggunakan kuesioner yang disusun dalam bentuk pernyataan dengan mengikuti Skala Likert. Selanjutnya pengujuan instrument penelitian dilakukan berdasarkan Uji Validitas dan Uji Reliabilitas. Untuk menjawab pertanyaan kualiatatif di gunakan metode kuesioner, observasi dan wawancara.

\section{Teknik Analisis Data}

Teknik analisis data dalam penelitian ini mengguankan metode triangulasi. Menurut Sugiyono (2011), dengan menggunakan strategi, pengecekan derajat kepercayaan penemuan hasil penelitian beberapa teknik pengumpulan data, pengecekan beberapa sumber data dengan metode yang sama. Triagulasi data untuk melakukan pengecekan terhadap penggunaan metode pengumpulan data. apakah informasi yang didapat dengan metode wawancara sama dengan metode observasi, begitu juga sebaliknya.

Sedangkan penelitian kuantitatif yaitu mendeskripsikan pengaruh promosi yang telah dilakukan digunakan tehnik analisis regresi berganda, Uji F (serempak), dan Uji $\mathrm{T}$ (parsial) merupakan alat uji statistik yang digunakan untuk mengetahui secara serempak dan secara parsial pengaruh variabel independen terhadap variabel dipenden pada tingkat kepercayaan 95\% $(\alpha=0,05)$. Data yang diperoleh dalam penelitian ini dengan menggunakan data statistik dengan menggunakan SPSS 21. 
HASIL

Karakteristik Sampel

Jumlah subjek yang berjenis kelamin laki- laki lebih tinggi sebanyak 99 orang $(90,00 \%)$ dibanding subjek berjenis kelamin perempuan sebanyak 11 orang $(10,00 \%)$.

Tim promosi melakukan pembuatan baliho, spanduk, leaflet, poster, brosur, branding car, dan stiker yang mereka pasang ditempat strategis. Selain itu tim promosi juga melakukan expo di berbagai daerah dan memasang iklan pada media cetak dan media elektronik walaupun dalam jumlah terbatas.

Adapun hambatan-hambatan yang diperoleh selama melakukan kegiatan promosi adalah dana promosi yang masih kurang untuk kegiatan periklanan.

Tim promosi dalam melaksanakan kegiatan personal selling dengan melakukan kunjungan atau sosialisasi ke sekolah-sekolah seperti SMU/SMK Negeri dan swasta. Biasanya tim promosi terdiri dari 2 sampai 3 orang yang bertugas untuk memberikan informasi secara langsung kepada pihak sekolah dan para siswa kelas 3 (tiga) yang akan mengikuti UAN.

Adapun faktor-faktor penghambat yang pada kegiatan personal selling adalah kurangnya SDM yang mampu berkomunikasi dengan baik dalam memberikan informasi secara langsung kepada masyarakat khususnya siswa yang akan segera mengikuti UAN. Selain itu tim promosi memanfaatkan media internet melalui jejaring sosial FB dan Website untuk membagikan gambar atau foto kegiatan workshop dan event yang telah mereka lakukan kepada pengguna jejaring sosial yang lain. Hal ini diharapkan dapat membuat citra kampus semakin baik di masyarakat, faktor penghambat lain

dalam kegiatan publisitas selama ini adalah masalah dana yang dirasa belum mencukupi untuk melaksankan kegiatan publisitas secara maksimal Hal lain yang juga dirasakan menjadi kendala adalah kurangnya SDM pada bagian kehumasan yang dapat merancang sebuah perencanaan komunikasi yang baik.

Selain kegiatan tersebut juga perlu melaksanakan kegiatan word of mouth selain melibatkan tim promosi kegiatan ini juga melibatkan seluruh pegawai dan Taruna Politeknik Bumi Akpelni untuk menyebarluaskan informasi yang positif mengenai kampus kepada masyarakat luas disekitar mereka seperti keluarga, teman, tetangga, ataupun orang yang mereka kenal, dalam kegiatan ini diharapkan orang yang mendapat informasi akan tertarik dan menyebarluaskan kembali informasi tersebut kepada orang lain.

Faktor yang menjadi kendala dalam kegiatan word of mouth adalah masalah yang bersifat internal, yaitu kurang baik dan harmonisnya hubungan komunikasi interpersonal antar sesama pegawai, hal ini menyebabkan komitmen untuk

menyebarluaskan informasi melalui word of mouth masih terkesan setengah-setengah serta menjadi cerminan yang kurang baik dari para Taruna terhadap kinerja organisasi Politeknik Bumi Akpelni Semarang.

\section{Analisis Uji Hipotesis}

Berdasarkan data penelitian yang dikumpulkan baik untuk variable terikat (Y) maupun variable bebas $\left(\mathrm{X}_{1}, \mathrm{X}_{2}\right)$, dengan persamaan sebagai berikut:

$$
\mathrm{Y}=\mathrm{aX} \mathrm{X}_{1}+\mathrm{bX}_{2}+\mathrm{c}
$$

Keterangan:

$\mathrm{Y} \quad=$ Variabel dependen (nilai yang diprediksikan)

$\mathrm{X}_{1}, \mathrm{X}_{2}=$ Variabel independen

a $\quad=$ Konstanta (nilai $Y^{\prime}$ apabila $X_{1}$, $\mathrm{X}_{2} \ldots . . \mathrm{X}_{\mathrm{n}}=0$ )

Persamaan tersebut diaplikasikan untuk melihat pengaruh, promosi dan kualitas pelayanan secara parsial dan simultan terhadap peningkatan jumlah Taruna, yang diolah dengan menggunakan bantuan program SPSS 21, maka diperoleh hasil perhitungan regresi linear berganda sebagai berikut:

Hasil pengujian statistic dengan metode uji $\mathrm{F}$ (serempak), di mana tingkat signifikan yang diperoleh lebih kecil yakni 0,0000 dari standar signifikan yakni 5\% 
atau 0,05 maka dapat disimpulkan bahwa Ha diterima atau promosi memiliki pengaruh yang signifikan terhadap peningkatan jumlah Taruna pada Politeknik Bumi Akpelni Semarang.

\section{PEMBAHASAN}

Penelitian ini menunjukkan bahwa dalam melakukan kegiatan promosi Politeknik Bumi Akpelni melakukan 4 (empat) bauran promosi, yaitu Iklan, Personal Selling, Publisitas, dan Word of Mouth. Iklan dan Publisitas adalah promosi yang dilaksanakan akan tetapi belum mendapatkan berpengaruh dalam peningkatan jumlah Taruna.

Dimensi Iklan dilakukan dengan pembuatan baliho, spanduk, leaflet, poster, brosur, branding car, umbul-umbul, dan stiker yang mereka pasang ditempat strategis. seperti pinggir jalan, sekitar lingkungan sekolah seperti SMU/SMK negeri dan swasta dan tempat keramain lainnya. Senada dengan Cangara (2013), mengatakan bahwa iklan adalah cara promosi yang sering digunakan dalam pemasaran komersil. Iklan dapat dilakukan melalui media, antara lain: Media elektronik (televisi, radio, film, bioskop, internet).;Media cetak (surat kabar, majalah, bulletin).;Media luar ruangan (papan reklame, electronic board yang dipsasang dipinggir - pinggir jalan yang bergerak secara elektronik, baliho, iklan pohon, spanduk, poster dan lain-lain).

Dimensi Personal Selling dilakukan dengan cara kunjungan atau sosialisasi ke sekolah- sekolah seperti SMU/SMK Negeri dan swasta. Biasanya tim promosi terdiri dari 2 sampai 3 orang yang bertugas untuk memberikan informasi secara langsung kepada pihak sekolah dan para siswa kelas 3 (tiga) yang akan mengikuti UAN.

Swastha (2002), mengatakan bahwa Personal selling adalah interaksi antar individu, saling bertemu muka yang dirujukan untuk menciptakan, memperbaiki, menguasai atau mempertahankan hubungan pertukaran yang saling menguntungkan dengan pihak lain.

Dimensi Publisitas dilakukan dengan cara membuat kegiatan workshop atau event di kampus dan di luar kampus kemudian mengundang wartawan dari media cetak untuk meliput kegiatan tersebut. Selain itu tim promosi memanfaatkan media internet melalui jejaring sosial Face Book dan website untuk membagikan gambar atau foto kegiatan workshop dan event yang telah mereka lakukan kepada pengguna jejaring sosial yang lain.

Sesuai dengan pendapat dari Swastha (2002), Publisitas adalah "Sejumlah informasi tentang seseorang, barang, atau organisasi yang disebar luaskan ke masyarakat melalui media tanpa dipungut biaya, atau tanpa pengawasan dari sponsor". Dimensi Word of Mouth dilakukan dengan cara melibatkan seluruh jajaran pegawai dan Taruna Politeknik

Bumi Akpelni untuk menyebarluaskan informasi yang positif mengenai kampus kepada masyarakat luas disekitar mereka seperti keluarga, teman, tetangga, ataupun orang yang mereka kenal, dalam kegiatan ini diharapkan orang yang mendapat informasi akan tertarik dan menyebarluaskan kembali informasi yang telah diterima tersebut kepada orang lain. Frisbee et al (2000), juga menyebutkan bahwa kelompok teman sebaya dapat menjadi salah satu bentuk pemasaran yang paling efektif. Melihat usia siswa SMU, teman sebaya merupakan salah satu faktor yang paling memiliki pengaruh penting dalam pengambilan keputusan.

Dari serangkaian kegiatan promosi yang telah dilakukan oleh tim pelaksana promosi hasil yang diperoleh belum maksimal, jika dibandingkan dengan keberadaan saudara dan alumni.

Faktor-faktor Penghambat Kegiatan Promosi adalah Dana Kegiatan Promosi yang diberikan untuk operasional kegiatan dirasa belum mencukupi untuk melaksanakan kegiatan promosi Iklan, Personal Selling, Publisitas, dan Word of Mouth secara maksimal guna mendapatkan hasil sesuai yang diharapkan. Sesuai dengan 
pendapat dari Irawan (1990), mengatakan bahwa "ada beberapa faktor yang mempengaruhi penentuan terbaik dari variabel - variabel promotion mix, salah satu faktor tersebuat adalah anggaran atau dana promosi, bila perusahaan/lembaga memiliki dana promosi yang besar, maka peluang untuk menggunakan iklan bersifat nasional juga besar."

Belum adanya Sumber Daya Manusia dalam bidang ilmu komunikasi pada tim promosi khusunya dalam bidang Kehumasan, ini menyebabkan perencanaan komunikasi pemasaran untuk kegiatan promosi tidak tersusun secara baik dan maksimal sehingga peningkatan jumlah mahasiswa belum sesuai dengan apa yang diharapkan.

Hubungan komunikasi interpersonal antar sesama pegawai yang kurang harmonis, menyebabkan komitmen untuk mendukung seluruh kegiatan promosi masih terkesan setengah-setengah. Kriyantono (2008), mengatakan bahwa tugas komunikasi sebuah lembaga pendidikan salah satunya adalah membangun citra korporat, dimana tugas komunikasi ini dilaksanakan oleh seluruh unsur lembaga (karyawan dan pimpinan) ikut andil dalam pembentukan citra ini, baik disadari atau tidak. Citra positif merupakan langkah penting menggapai reputasi lembaga di mata khalayak.

\section{KESIMPULAN}

Dalam melakukan promosi, Politeknik Bumi Akpelni menggunakan 4 (empat) bauran promosi, yaitu Iklan, Personal Selling, Publisitas, dan Word of Mouth dan melalui pendekatan dengan saudara dan alumni yang sudah menduduki jabatan di berbagai lembaga pemerintahan dan perusahaan-perusahaan swasta di seluruh wilayah Indonesia.

Melalui dimensi saudara dan alumni adalah pengaruh promosi yang paling berpenagruh terhadap peningkatan jumlah penerimaan calon taruna baru.

Dimensi iklan (advertising) adalah merupakan dimensi strategi promosi yang berpengaruh kecil terhadap peningkatan jumlah penerimaan calon taruna baru, sedangkan yang tidak memiliki pengaruh yang signifikan adalah publisitas. Secara keseluruhan variabel promosi memiliki pengaruh yang signifikan terhadap peningkatan jumlah penerimaan taruna baru. Kendala - kendala yang ditemui selama kegiatan promosi dilakukan adalah minimnya dana yang diberikan untuk seluruh kegiatan promosi yang dilakukan, sehingga kegiatan promosi kurang memberikan kontribusi yang maksimal terhadap peningkatan jumlah mahasiswa, kurangnya SDM pada bidang komunikasi khususnya dalam merancang perencanaan kegiatan promosi yang baik. Oleh karena itu promosi yang telah dilakukan seperti Iklan, Word Of Mouth, Publisitas, Dan Personal Selling harus lebih dikembangkan dan tetap menggandeng dengan saudara dan alumni Politeknik Bumi Akpelni. Selanjutnya Tim Promosi hendaknya merencanakan anggaran promosi yang efektif dan efisien untuk setiap kegiatan promosi, serta lembaga Humas harus difungsikan sesuai dengan fungsinya dan mengembangkan SDM khusunya dalam bidang ilmu komunikasi.

\section{DAFTAR PUSTAKA}

Augusty F. 2006. Metode Penelitian Manajemen, Edisi Kedua : Penerbit BP-UNDIP Semarang.

Cangara Hafied. 2013. Perencanaan dan strategi komunikasi, Rajawali Pers

Gitosudarmo Indriyo.2004. Marketing dan Kasus-kasus Pilihan, Penerbit Centre of Academic Publishing Service (CAPS).

Irawan 1990. Manajemen Pemasaran Modern.Liberty Yogyakarta

Lupiyoadi, R. 2001.

Manajemen Pemasaran Jasa: Teori dan Praktek. Jakarta:

Penerbit Salemba Empat Jakarta.

Kriyantono Rachmat. 2008. Teknik Praktis Riset Komunikasi.

Kencana Prenada Media Group. Jakarta. 
Ristiyanti Prasetijo dan Ihalauw, Jhon J.O.I. 2005. Perilaku Konsumen. Yogyakarta: Penerbit Andi.

Sugiyono 2013. Metode Penelitian Kuantitatif, Kualitatif Dan R \& D. Cetakan ke-19. Bandung: Penerbit ALFABETA, CV.

Susatyo H. 2014. Basic Marketing. Edisi Pertama. Cetakan Pertama. Yogyakarta: Penerbit Gosyen
Publishing.

Swastha. 2002. Manajemen Pemasaran. Edisi Kedua. Cetakan Kedelapan. Jakarta: Penerbit Liberty.

Tierab P. Fhebrian dan Mulawarman Enrico. 2009. Strategi Promosi Universitas Swasta dalam Menarik Minat Mahasiswa baru Jakarta STIMIK Bina Nusantara. 